\section{First record of Coelognathus radiatus (Boie, 1827) (Reptilia: Colubridae) from the Ananthagiri Hills, Eastern Ghats, India}

\author{
S.M. Maqsood Javed ${ }^{1}$, Farida Tampal ${ }^{2}$ \\ \& C. Srinivasulu ${ }^{3}$
}

$1 \& 2$ World Wide Fund for Nature-India (WWF), APSO, 818, Castle Hills, Road No. 2, Near NMDC, Vijayanagar Colony, Hyderabad, Andhra Pradesh 500057, India

${ }^{3}$ Wildlife Biology Section, Department of Zoology, University College of Science, Osmania University, Hyderabad, Andhra Pradesh 500007, India

Email: ${ }^{1}$ javedwwf2007@gmail.com

In India, the genus Coelognathus Fitzinger, 1843 is represented by three species and one subspecies - $C$. flavolineatus (Schlegel, 1837), C.h. helena (Daudin, 1803), C. radiatus (Boie, 1827) and C.h. monticollaris (Schulz, 1992). C. flavolineatus is endemic to the

Date of publication (online): 26 August 2010

Date of publication (print): 26 August 2010

ISSN 0974-7907 (online) | 0974-7893 (print)

Editor: Ashok Captain

\section{Manuscript details:}

Ms \# 02313

Received 115 September 2009

Final revised received 01 July 2010

Finally accepted 30 July 2010

Citation: Javed, S.M.M., F. Tampal \& C. Srinivasulu (2010). First record of Coelognathus radiatus (Boie, 1827) (Reptilia: Colubridae) from the Ananthagiri Hills, Eastern Ghats, India. Journal of Threatened Taxa 2(9): $1172-1174$

Copyright: (C) S.M. Maqsood Javed, Farida Tampal \& C. Srinivasulu 2010. Creative Commons Attribution 3.0 Unported License. JoTT allows unrestricted use of this article in any medium for non-profit purposes reproduction and distribution by providing adequate credit to the authors and the source of publication.

Acknowledgements: The authors are very much thankful to Shri Hitesh Malhotra, IFS, Principal Chief Conservator of Forest (Wildlife) and Chie Wildlife Warden, Andhra Pradesh; Shri. R. Hampaiah, Chairman and Shr V.B. Ramana Murthy, Member Secretary, Andhra Pradesh Biodiversity Board for their constant support and encouragement. SMMJ and FT expresses gratitude to Shri Anil Kumar V. Epur, Chairman, WWF-AP State Committee, Hyderabad and Shri Ravi Singh, Secretary General \& CEO, WWF-India, New Delhi for constant support and encouragement. We express our thanks to Shri Swaranjit Sen, IPS (Retd.), Chairman, Shri B. Venkatesham, IAS, Managing Director and Shri P.V. Ramana Reddy, IFS Executive Director, Andhra Pradesh Tourism Development Corporation, Hyderabad for constant support and permitting us to conduct biodiversity studies in APTDC Eco-tourism sites. CS thanks Prof. T. Tirupathi Rao, Vice Chancellor, Osmania University and the Head, Department of Zoology, Osmania University, Hyderabad for encouragement and facilities. We thank Mr. R. Sreekar and Mr. M. Seetharamaruju Department of Zoology, Osmania University for sharing literature. Lastly, we would like to thank Mr. P.S.M. Srinivas, Manager Corporate for exploring new places and all the WWF-Staff of APSO, Hyderabad for their constant support and timely suggestions.

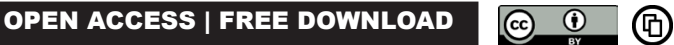

Andaman Islands; C.h. helena is very common throughout mainland India while the subspecies C.h. monticollaris is presently reported only from the Western Ghats. Unpublished reports of monticollaris from elsewhere are beyond the scope of this note. In India, Copper-headed Trinket Snake Coelognathus radiatus (Boie, 1827) was known to occur from Uttarakhand to Arunachal Pradesh, in parts of Madhya Pradesh, Chhattisgarh, Orissa, West Bengal and Sikkim.

Recently, the World Wide Fund for Nature-India (WWF), Andhra Pradesh State Office in collaboration with Andhra Pradesh Tourism Development Corporation (APTDC), has initiated a survey-based biodiversity documentation project in APTDC Eco-tourism sites. During the first phase of biodiversity survey at APTDC Eco-tourism sites in the Ananthagiri Hills in northern Eastern Ghats (Tyda, Borra, Ananthagiri and Araku Valley), we recorded the presence of $C$. radiatus in the coffee plantations at Ananthagiri. Through this communication, we report the first record of this species from Ananthagiri Hills, northern part of Eastern Ghats, Andhra Pradesh, India.

During field surveys between 15 and 25 February 2009 in the study area (0530 to $1800 \mathrm{hr}$ ), we encountered a live specimen of $C$. radiatus while it was crossing the road at about $1310 \mathrm{hr}$ near a coffee plantation close to Ananthagiri Village $\left(18^{\circ} 15^{\prime} \mathrm{N} \& 82^{\circ} 59^{\prime} \mathrm{E}\right)$, Vishakapatnam District, Andhra Pradesh on 22 February 2009 (Image 1). It was photographed and released after collecting scalation data along with measurements. The specimen was identified based on descriptions available in the literature (Smith 1943; Schulz 1996; Daniel 2002; Whitaker \& Captain 2004). Photo vouchers (NHM.OU.REP.PV.15/16/17/182009) have been deposited in the collection of the Natural History Museum of Osmania University, Hyderabad.

\section{Description}

It is a large and relatively slender snake, with its narrow head slightly set off from the neck. Snout is slightly rounded and approximately twice the length of eye diameter. Tail is relatively shorter and slender. The ventral keels are fairly well developed. The cross-section of the body is higher than wide. Eyes are relatively large and have a golden-yellow iris (Image 5). Tongue brownish-violet (Image 5). Head is copper or dull orange in colour; a transverse black stripe runs across head with black streaks leading to the eyes and two backwards. Two black stripes are present below eyes. Three narrow black stripes radiate from the eyes, one directly below the eye, and another obliquely to the angle of the mouth and a third fuses with the narrow collar band on the nape (Images 3, 4 \& 5). Body is yellowish-brown, anteriorly adorned with longitudinal black stripes, usually three on each side, median not connected to the black collar. 


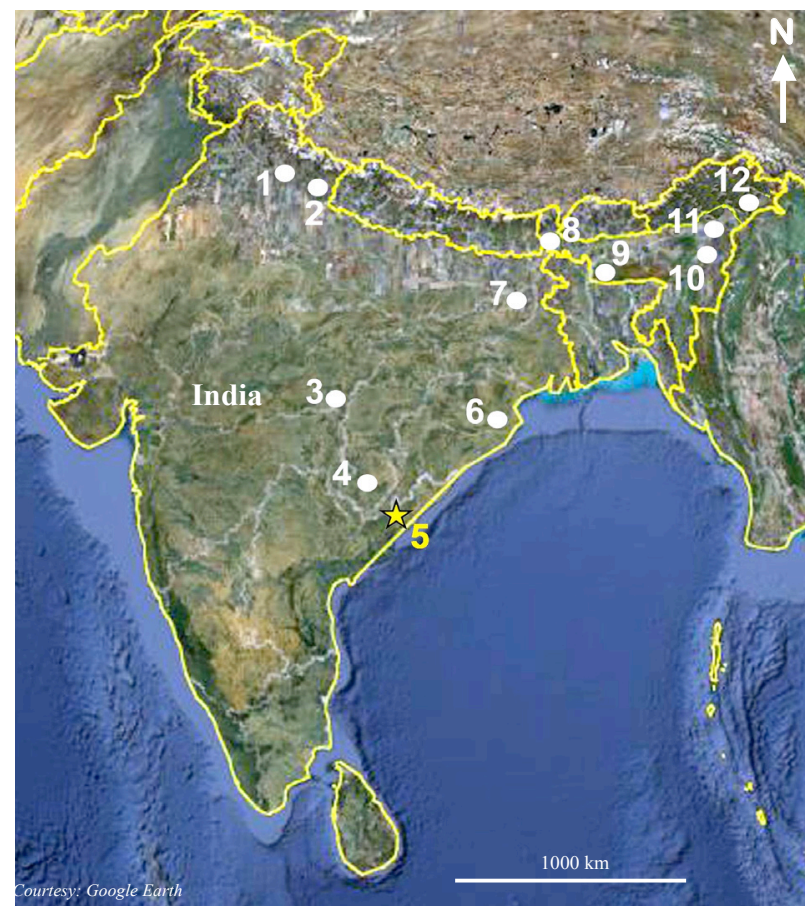

Image 1. Satellite image showing a map depicting C. radiatus distribution range in India.

1- Dehradun; 2 - Almora; 3 - Balaghat; 4 - Bastar;

5 - Ananthagiri (present study); 6 - Cuttack; 7 - Purnia;

8 - Darjeeling; 9 - Meghalaya; 10 - Dibrugarh; 11 - Kohima; 12 - Miao.

Posteriorly, stripes disappear; belly pale yellow, mottled with grey. Skin is checkered black, blue-grey and bright yellow anteriorly, visible when the snake inflates itself under aggression (Image $2 \& 5$ ). Total body length of the Ananthagiri specimen was approximately $2.15 \mathrm{~m}$.

Scutellation: Two postoculars, 2+2 temporals; 1 preocular, 9 supralabials (with $4^{\text {th }}, 5^{\text {th }}$ and $6^{\text {th }}$ in contact with the eye; among which the $6^{\text {th }}$ supralabial shield is largest and is arched around and behind the eye) (Image 4); 10 infralabials; 19 dorsals (mid-body), weakly keeled on the back and smooth on the sides; 250 ventral, 106 subcaudals and anal plate undivided.

Biology: We sighted a large $C$. radiatus while it was crossing the road around mid-afternoon (1310hr) near a coffee plantation close to the Ananthagiri Village. This species has been recorded from gardens, crop fields adjacent to the forests, open areas and water logged areas (Smith 1914; Wall 1914). According to Günther (1864) it is equally diurnal and nocturnal. The specimen was very aggressive. Both Smith (1914) and Wall (1914) have described in detail how $C$. radiatus, when annoyed, flattens its neck vertically, throwing itself into an S-shaped loop, opening its mouth and thus remains alert, ready to defend itself vigorously against attack. The black lateral bars that become visible by this behavior may act as a warning to enemies (Image 2).

Status: C. radiatus is treated as widely distributed

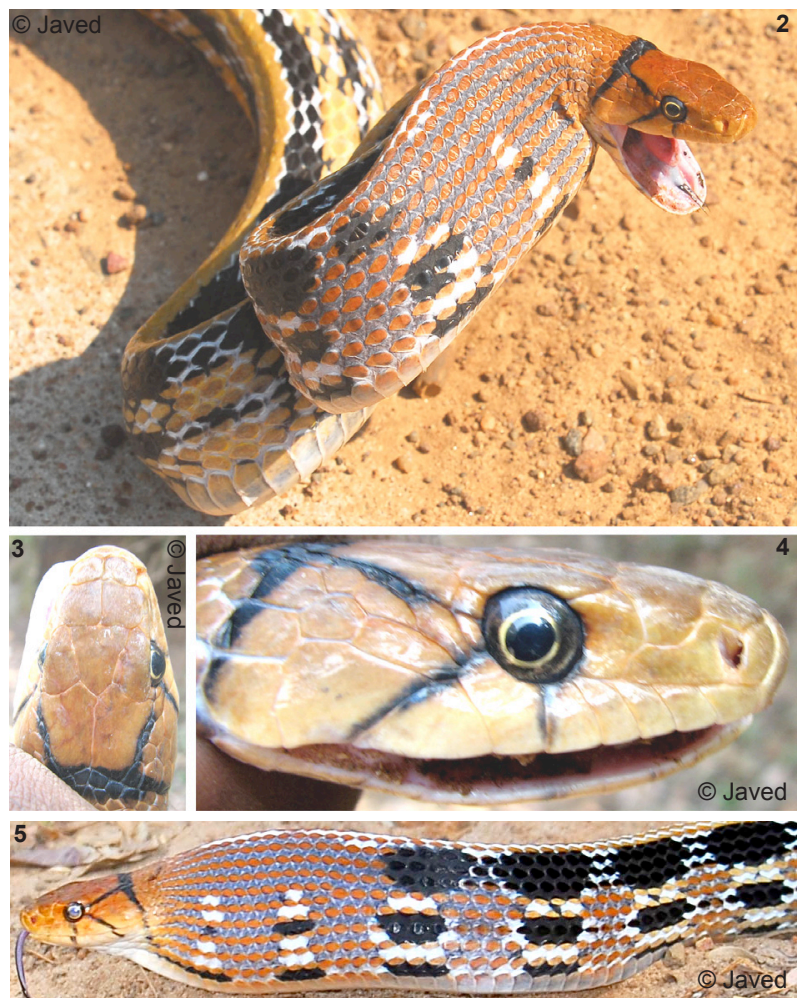

Images 2-5. Coelognathus radiatus.

2 - Dorsolateral aspect of $C$. radiatus (live, photo

voucher-15) displaying defensive posture; 3 - Dorsal aspect of $C$. radiatus (live, photo voucher-16) head showing scales and markings; 4 - Lateral aspect of $C$. radiatus (live, photo voucher-17) head showing eye, lateral head scalation and nare; 5 - Lateral aspect of $\boldsymbol{C}$. radiatus (live, photo voucher-18) head and anterior body showing tongue and colouration patterns.

species and listed as Lower Risk Least Concern (Molur \& Walker 1998).

The present record from the Ananthagiri Hills suggests that the species' natural distribution in India is greater than was previously thought (Image 1). Furthermore, it calls for further systematic and long-term surveys in the Eastern Ghats of Andhra Pradesh to document herpetofaunal diversity in totality. With this addition the number of snake species known from Andhra Pradesh reaches 41 (Sanyal et al. 1993; Daniel 2002; Whitaker \& Captain 2004; Rao et al. 2005; Srinivasulu \& Das 2008).

\section{REFERENCES}

Daniel, J.C. (2002). The Book of Indian Reptile and Amphibians. Bombay Natural History Society, Oxford University Press, New Delhi, viii+ 238pp.

Günther, A. (1864). The Reptiles of British India. Published for the Ray Society by Robert Hardwicke, London, pls.I$\mathrm{XXVI+452pp.}$

Molur, S. \& S. Walker (eds.) (1998). Reptiles of India. Biodiversity Conservation Prioritisation Project (BCPP) India, Endangered Species Project - Conservation Assessment 
and Management Plan (C.A.M.P.) workshops. Zoo Outreach Organisation \& CBSG, India, Coimbatore, India. 175pp.

Rao, K.T., H.V. Ghate, A.M. Sudhakar, S.M.M. Javed \& I.S.R. Krishna (2005). Herpetofauna of Nallamalai Hills with eleven new records for the region including ten new records for Andhra Pradesh. Zoos' Print Journal 20(1): 1737-1740.

Sanyal, D.P., B.D. Gupta \& N.C. Gayen (1993). Reptilia. In Ghosh, A.K. (ed). State Fauna Series 5. Fauna of Andhra Pradesh, Part I. Zoological Survey of India, Calcutta, 63pp.

Schulz, K-D. (1996). A Monograph of The Colubrid Snakes of The Genus Elaphe Fitzinger. Koeltz Scientific Books, 439pp.

Smith, M.A. (1914). The snakes of Bangkok - Part 3. Journal of the Natural History Society of Siam 1(2): 93-104.

Smith, M.A. (1943). The Fauna of British India, Ceylon and Burma, Including the Whole of the Indo-Chinese SubRegion. Reptilia and Amphibia - 3 (Serpentes). Today and
Tomorrow's Printers \& Publishers, New Delhi, Indian Reprint 1974, 583pp.

Srinivasulu, C. \& I. Das (2008). The herpetofauna of Nallamala Hills, Eastern Ghats, India: an annotated checklist, with remarks on nomenclature, taxonomy, habitat use, adaptive types and biogeography. Asiatic Herpetological Research 11: 110-131.

Wall, F. (1903). A prodromus of the snakes hitherto recorded from China, Japan, and the Loo Choo Islands: with some notes. Proceedings of the Zoological Society of London 84-102.

Wall, F. (1914). A popular treatise on the common Indian snakes. Journal of the Bombay Natural History Society XXIII: 206215.

Whitaker, R. \& A. Captain (2004). Snakes of India - The Field Guide. Chennai, India. Draco Books, xiv+481pp. 